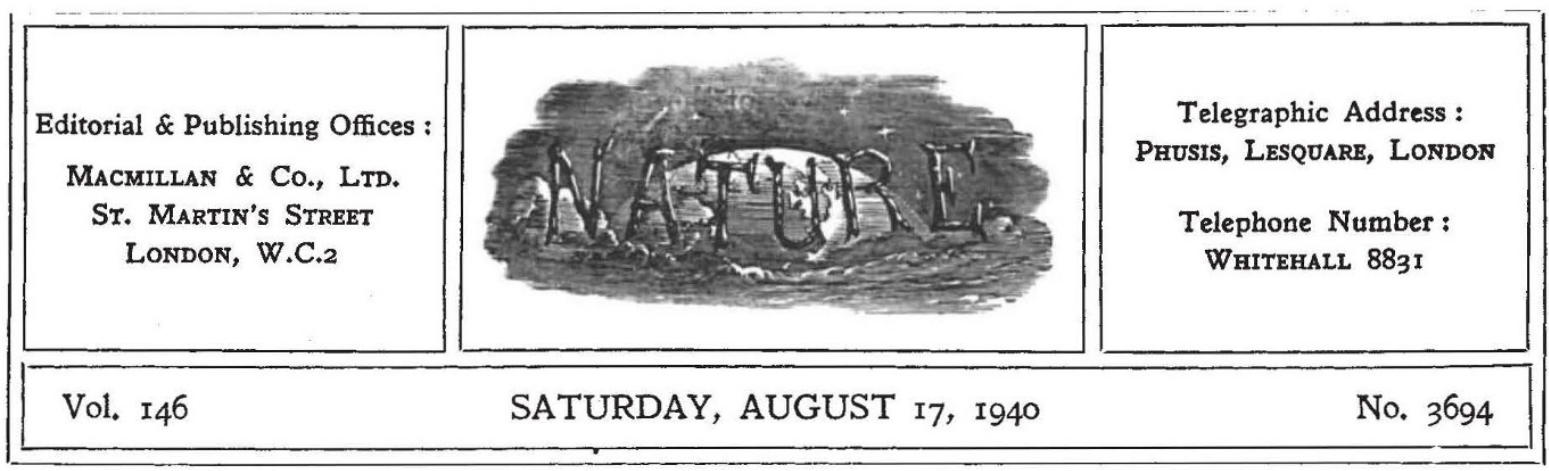

\title{
PREPARING FOR A NEW WORLD ORDER
}

$\mathrm{T}$ HE rapidity with which the march of events has thrown on Great Britain the main and almost the sole burden of the defence of the liberties and traditions of Western civilization, endows with something of prophetic vision the Prime Minister's declaration on June 4 of our determination to continue the struggle: "if necessary, for years, if necessary, alone". Under that burden we can have but one war aimvictory. Inexorably other discussion on war aims has for the time being to be thrust into the background, like the shattered solemn declaration of the Supreme War Council of March 28, with all the hopes it seemed to foreshadow of a new European order based on Anglo-French co-operation.

Such co-operation is for the time being impossible. On us now falls the material burden of staying the onslaught of aggression and barbarism and making safe for mankind those moral and spiritual values to which we owe all that is best in our civilization.

It is well that we should remember, however, that although the material burden is largely ours alone, we have the sympathy and often active support not only of those nations such as Czechoslovakia, Poland, Norway, Holland, Belgium whose liberation waits on the success of our arms, or of the great countries across the Atlantic, but also of many Frenchmen still in France. As regards those Frenchmen who have come to Great Britain, the memorandum of agreement recently made between the British Government and General de Gaulle provides for a French force of volunteers including naval, land and air units and scientific and technical personnel, who will fight and work for the Allied cause; further, such volunteers will be given special facilities for acquiring British nationality.

None the less, if we are to obtain in due course the full results of our efforts, for our allies and well-wishers as for ourselves, we must turn our attention to the history of the last twenty-five years, to probe the real causes of our failure twenty years ago to build a durable world-order, and to be ready to avoid the mistakes of the past when the opportunity to build again is vouchsafed us. As Sir Herbert Parsons points out in a letter in this issue of NATURE (p. 230), it is not too early to take steps to consider the future in the light of experience of the past two decades.

It is this point of view that gives topical interest to Prof. E. H. Carr's 'The Twenty Years' Crisis" and to the more recent volumes of Dr. Maxwell Garnett and Mr. Arthur Bryant referred to below*. Prof. Carr attempts to analyse the underlying and significant, rather than the immediate and personal, causes of the present war, and he opens with a discussion of the science of international politics which should make a direct appeal to the man of science. None the less, the scientific worker who reads with keen appreciation Prof. Carr's opening chapter on the beginnings of the science of international politics, with its insistence on the relation between purpose and thought, its reminder that political thought itself is a form of political action, that political science is the science not only of what is, but of what ought to be, its warning about distinguishing the analysis of what

\footnotetext{
* The Twenty Years' Crisis, 1919-1939: an Introduction to the Study of International Relations. By Prof. Edward Hallett Carr. Pp. $x v+313$. (London: Macmillan and Co., Ltd., 1939.) 10s. 6d. net. A Lasting Peace. By Dr. Maxwell Garnett. With some Chapters on the Basis of German Co-operation, by Dr. H. F. Koeppler. Pp. 288. (London : George Allen and Unwin, Ltd., 1940.) 78. 6d. net.

Unfinished Victory. By Arthur Bryant. Pp. xxxvi+271. (London: Macmillan and Co., Ltd., 1940.) 88. 6d. net.
} 
is from aspiration about what should be, may yet put the whole book down with some sense of disappointment. Despite all his keen analysis of particular situations, his historian's impartiality and his shrewd comments, Prof. Carr appears to lead us nowhere. His concluding analysis of the pros. pects of a new international order lacks conviction and definition and offers little that is constructive.

The reason for this is easily found. Prof. Carr insists that Utopia and reality are the two facets of political science, and the whole book is largely an essay or commentary on the implications of the opposition between Utopia and reality in the light of the history of the past twenty years. Unfortunately, Prof. Carr does not carry his analysis of political objectives or ideals far enough. The distinction between reality and Utopia is never made clear to the reader. The two common meanings of Utopia are confused, and generally the analysis of terms, events or causes is not pushed far enough. Partly as a result of this, Prof. Carr's obvious desire for strict impartiality leads him to do something less than justice to the attempts to build a new world order, whether through the League of Nations, collective security, federation or the like. The opponents of world co-operation are invariably given the benefit of the doubt, despite a reminder that it is by no means certain that a direct appeal to the motive of sacrifice will always fail.

Prof. Carr, in fact, largely overlooks or underestimates psychological factors, and valuable as his work may be as a corrective to wishful thinking, or as a contribution to putting the factors of power and morality in their proper perspective in international politics, or for its analysis of the relations between law and change, it does not make the significant contribution to the science of international relations which might be hoped from its opening part. It should indeed be read with L. Woolf's stimulating essay "Utopia and Reality" in the Political Quarterly (April-June 1940)—itself essentially a thoughtful review of the book. None the less there are few recent books which are more worthy of attention from those who are attempting to think out the lines of the new world order.

Prof. Carr regards the fundamental difficulty of reconciling the good of the nation with the good of the world community as due to the breakdown both of the Darwinian doctrine which identifies the good of the whole with the good of the fittest and contemplates without repugnance the elimination of the unfit, and of the doctrine of a natural harmony of interests which, in his opinion, has lost such foundation in reality as it once had and becomes inevitably a cloak for the vested interests of the privileged. Our task of exploring the ruins of our international order and discovering on what fresh foundations we may hope to rebuild it must be considered from the point of view of power and of morality. The form of the future international order is closely bound up with the future of the group unit, and it may well be that the concept of sovereignty will become even more blurred and indistinct. The best hope of progress towards international conciliation seems to lie along the path of economic reconstruction.

L. Woolf dissents from Prof. Carr's view that the doctrine of harmony of interests has lost its validity. He points out that individuals as well as nations often fail to recognize their real interests, and that generally and in the long run common interests are more real politically than conflicting interests. The real international problem which confronts Europe and civilization to-day is not a choice between Utopia and reality but between the psychology of conflicting interests and the organization of power politics on one hand, and the psychology of common interests and the organization of international co-operation on the other. Woolf, however, is himself too legalistic. The transition to a durable peace and a more equitable social order must be in the sequence order, law and good government, as Sir Alfred Zimmern remarks, not law and then order. "No paper plan," insisted Lord Halifax, in a broadcast last autumn, "will endure that does not freely spring from the will of the people who alone can give it life."

Prof. Carr would doubtless concur that education is one of the essential tasks in the establishment of world order. That question is discussed in two of the most important chapters of Dr. Maxwell Garnett's book. The world commonwealth of the future can only be held together by a world loyalty and the invisible bond of ideals, and the problem of building world order on a lasting basis belongs in the long run no less to psychology and education than to politics and economics.

Dr. Garnett deals with the immediate causes of the present conflict and the breakdown of international co-operation. In some respects his analysis of the history of the last twenty-five years is more realistic than Prof. Carr's. In contrast to the latter's cool detachment, Dr. Garnett does not conceal the fact that he is on the side of the angels. $\mathrm{He}$ is concerned, however, to lay bare the causes of the 
failure of the first experiment at international co-operation and world order through the League, and his survey and criticism cannot be dismissed as one-sided or superficial. The ordinary citizen will find his argument much easier to follow, if in some respects less profound, than that of Prof. Carr, and the book is a notable contribution to the educational work which must proceed, both during the War and after it, before we can achieve a lasting peace.

Dr. Garnett quotes the text of the Solemn Declaration of the Supreme War Council of March 28 and obviously visualizes the gradual development of the new international order out of that Anglo-French co-operation. Nor need we fear that the act of one French Government need compel the abandonment of all hope that that co-operation may yet prove the stepping-stone to such a new order when the menace of aggression and barbarism has been removed.

This factor gives special significance to the last part of the book, in which Dr. H. F. Koeppler, under the title "The Basis of German Co-operation", gives a succinct review of German history, particularly the unification of Germany, and discusses its bearing, as well as that of the rise of Nazism, on the establishment of a lasting peace. It is here, as in its stress on the importance of education, that the book touches common ground with Mr. Bryant's "Unfinished Victory", the finest in quality and most moving of the three. Writing with all the impartiality of the historian, Mr. Bryant gives us a study of Germany history from 1916 and an interpretation of Hitler and Nazism which can scarcely fail to facilitate the creation of an understanding between the British people and the Reich when the War has come to an end. The heart of the book is in the introductory "Historian's Testament", with its hope that the book may help in the right use of victory when it has been won for us by the valour and endurance of our race.

Mr. Bryant's sincerity and balance can scarcely fail of their purpose to make it a little easier for the people of Great Britain to understand the causes of the violence and aggression of our enemy, and as he points out, we can only achieve our end of freeing Europe from the effects of that violence and aggression when we have reached that understanding. But few who read the book will fail to be grateful also for the interpretation of the national spirit given in a passage written after the march to Prague. There is in these pages a quality of the spirit which is the surest token. that victory won once again will this time not be unfinished or in vain.

These books are permanent evidence that in the midst of this struggle there are those who, recognizing all that it demands of us, are looking to what lies beyond. The reader may well find in their pages, not vain visions or castles in the air, but the quality of mind which will strengthen him to endure all that may be asked of him in the ordeal that lies immediately ahead; and, when victory is won, to play his part in the travail out of which the new world order will be born. The three books together make no mean contribution to fundamental thinking on the enduring values of Western civilization for which we contend, and on their enthronement in a new order, social as well as international, from which, not change or evolution, but war has been eliminated. Such thought running ahead of realization, as A. N. Whitehead reminds us, is the condition of quick transition to new types of civilization. That it should proceed in the midst of so stern a struggle as that in which we are now engaged may indeed be the earnest of final victory.

\section{ARE WE ALONE IN THE UNIVERSE?}

\section{Life on Other Worlds}

By Dr. H. Spencer Jones. Pp. xiv $+259+17$ plates. (London: English Universities Press, Ltd., 1940.) 7s. $6 d$. net.

$\mathrm{A}^{\mathrm{s}}$ every professional astronomer knows, there is a vast population of laymen for whom the really exciting problems of astronomy are not those associated with the finiteness or supposed expansion of space, or the sources of stellar energy, but with the canals on Mars and the possibility of life on Mars. In this little book of 250 pages, the Astronomer Royal tells us of the findings of modern astronomy on these latter questions, and much besides, in a way that will not only interest the layman, but the professional scientist as well. It is a model of what such a book should be, popular and scientific at the same time, clear but concise 